\title{
ANALISIS FAKTOR-FAKTOR YANG MEMPENGARUHI PENERIMA BERAS RASKIN MENGGUNAKAN REGRESI LOGISTIK BINER DENGAN GUI R
}

\author{
Agustinus Salomo Parsaulian ${ }^{1}$, Tarno ${ }^{2 *}$, Dwi Ispriyanti ${ }^{3}$ \\ ${ }_{1,2,3}$ Departemen Statistika FSM Universitas Diponegoro \\ *e-mail: tarnostat@gmail.com
}

\begin{abstract}
The Rice Subsidy Program for Low-Income Communities or the Raskin Program is one of the government's programs to eradicate poverty. However, in practice, determining the criteria for Raskin recipients is a complicated problem. The Raskin program is a cross-sectoral national programboth horizontally and vertically, to help meet the rice needs of low-income citizens. Determining the criteria for Raskin recipients is often a complicated is sue. This study aims to analyze the classification of the Target Households (RTS) for the Raskin Program. The method used is binary logistic regression by utilizing R GUI. Binary logistic regression method is a method to find the relationship between independent and dependent variables, with a binary or dichotomous dependent variable. The data used is the March 2018 National Socio-Economic Survey (Susenas) data for Brebes Regency. The independent variables used in this study are the criteria for determining poor households, namely the area of the house, floor type of the house, wall type of the house, defecation facilities, lighting used, fuel used, ability to buy meat/milk, education level of the head of the household, and the capacity of installed electricity in the main residence. The results of the analysis show that in the final model, the variables that significantly affect the classification of RTS are the ability to eat healthy food, the capacity of installed electricity in the main residence, the education level of the head of the household, and defecation facilities with an accuracy value of $85.4 \%$.
\end{abstract}

Keywords: Raskin Program, Binary Logistic Regression, R GUI

\section{PENDAHULUAN}

Kesejahteraan rakyat suatu negara pada hakikatnya adalah bagian dari tanggung jawab dari pemerintah negara tersebut, seperti halnya yang tertulis di alinea keempat pembukaan Undang-Undang Dasar 1945 bahwa salah satu tujuan didirikannya pemerintahan Indonesia adalah untuk memajukan kesejahteraan umum. Salah satu bentuk kebijakan konkret yang dilaksanakan pemerintah Indonesia dalam menjalani komitmennya tersebut adalah menerapkan Program Subsidi Beras bagi Masyarakat Berpendapatan Rendah atau Program Raskin. Menurut Bulog (2019) penyaluran Raskin dimulai sejak krisis moneter pada tahun 1998 dengan tujuan untuk memperkuat ketahanan pangan rumah tangga terutama rumah tangga miskin. Penentuan kriteria penerima Raskin seringkali menjadi persoalan yang rumit. Hal ini disebabkan oleh beberapa faktor, yaitu ketersediaan anggaran, masih adanya RTM yang tidak terdaftar sebagai RTS di BPS, dan kendala dalam pencapaian ketepatan indikator.

Salah satu metode statistika yang bisa dilakukan untuk mempermudah pengklasifikasian RTS, adalah menggunakan metode regresi logistik biner. Menurut Nachrowi dan Hardius (2002), regresi merupakan suatu metode yang digunakan untuk menganalisis hubungan antara variabel yang diekspresikan dalam bentuk persamaan yang menyatakan hubungan antara variabel terikat $\mathrm{Y}$ dengan satu atau lebih variabel bebas $x_{1}, x_{2}, \ldots, x_{p}$. Hosmer dan Lemeshow (2000) menyatakan bahwa analisis regresi logis tik adalah analisis regresi yang digunakan untuk mencari hubungan antara variabel bebas dan variabel terikat yang bersifat diskrit yang mempunyai satu atau lebih nilai.

Tujuan dari penelitian ini adalah menentukan model klasifikasi rumah tangga penerima Raskin di Kabupaten Brebes menggunakan metode regresi logistik biner dan menentukan variabel-variabel yang mempengaruhi pengklasifikasian rumah tangga 
penerima Raskin, sehingga mempermudah dalam penentuan kriteria penerima Raskin dan membantu melancarkan penyaluran Raskin. Dalam kasus penerimaan beras Raskin ini, variabel bebas yang digunakan adalah kriteria penerimaan raskin. Menurut BPS (2012), dalam penetapan rumah tangga miskin terdapat 14 kriteria yang harus terpenuhi. Variabel terikat yang digunakan adalah status penerimaan raskin di masing-masing RTM, apakah RTM sudah menerima raskin atau belum.

\section{TINJAUAN PUSTAKA}

\subsection{Program Beras Raskin}

Raskin (Beras untuk Rumah Tangga Miskin) merupakan subsidi pangan yang diperuntukkan bagi keluarga miskin. Program ini pada awalnya dimulai pada tahun 1998 pada saat krisis pangan untuk memperkuat ketahanan pangan rumah tangga, terutama Rumah Tangga Miskin (RTM). Pada awalnya program Raskin bernama program Operasi Pasar Khusus (OPK), yang kemudian diubah menjadi Program Subsidi Beras bagi Masyarakat Berpendapatan Rendah pada tahun 2008 atau program Raskin, dengan perluasan Rumah Tangga Sasaran dari RTM saja menjadi Rumah Tangga Rentan atau Hampir Miskin.

\subsection{Me tode Regresi Logistik Biner}

Menurut Hosmer dan Lemeshow (2000), metode regresi logistik dapat digunakan untuk mencari hubungan antara variabel bebas dan variabel terikat yang bersifat diskrit yang mempunyai satu atau lebih nilai. Metode regresi logistik yang khusus digunakan untuk variabel terikat yang bersifat dikotomi dinamakan metode regresi logistik biner. Model regresi logistik adalah sebagai berikut:

$\pi\left(\boldsymbol{x}_{\boldsymbol{i}}\right)=\frac{\exp \left(\beta_{0}+\beta_{1} x_{1 i}+\ldots .+\beta_{p} x_{p i}\right)}{1+\exp \left(\beta_{0}+\beta_{1} x_{1 i}+\ldots .+\beta_{p} x_{p i}\right)}$

dengan transformasi logitnya adalah sebagai berikut:

$$
\begin{aligned}
g\left(\boldsymbol{x}_{\boldsymbol{i}}\right) & =\ln \left[\frac{\pi\left(\boldsymbol{x}_{\boldsymbol{i}}\right)}{1-\pi\left(\boldsymbol{x}_{\boldsymbol{i}}\right)}\right] \\
& =\beta_{0}+\beta_{1} x_{1 i}+\ldots+\beta_{p} x_{p i}
\end{aligned}
$$

\subsection{Estimasi Parameter}

Menurut Hosmer dan Lemeshow (2000), metode estimasi yang digunakan untuk mengestimasi parameter pada model regresi logistik biner adalah metode Maximum Likelihood Estimation (MLE). Hardius dan Nachrowi (2002) menyatakan bahwa jika diberikan sebuah fungsi logistik berbentuk $L(x)=\beta_{0}+\beta_{1} x_{1}+\beta_{2} x_{2}+\cdots+\beta_{p} x_{p}$ dengan fungsi likelihood $L\left(\beta_{1}, \beta_{2}, \ldots, \beta_{p}\right)$ atau $l(\beta)$, maka metode MLE mencari nilai $\widehat{\beta_{1}}, \widehat{\beta_{2}}, \ldots, \widehat{\beta_{p}}$ yang dapat memaksimumkan nilai $l(\beta)$ untuk mendapatkan nilai $l(x)$ yang paling mendekati dengan observasi.

\subsection{Uji Signifikansi Parameter}

Langkah berikutnya setelah melakukan proses estimasi parameter adalah pengujian parameter yang signifikan terhadap model. Uji signifikansi parameter yang digunakan adalah uji rasio likelihood dan uji Wald.

\subsubsection{Uji Rasio Likelihood}

Uji rasio likelihood digunakan untuk menguji apakah variabel bebas mempengaruhi model yang didapat dari estimasi parameter secara signifikan atau tidak.

Hipotesis: 
$\mathrm{H}_{0}: \beta_{1}=\beta_{2}=\ldots=\beta_{p}=0$ (variabel independen tidak berpengaruh terhadap variabel dependen)

$\mathrm{H}_{1}$ : sekurang-kurangnya terdapat satu $\beta_{j} \neq 0$, dengan $j=1,2, \ldots, p$ (ada variabel independen yang mempengaruhi variabel dependen)

Statistik uji:

$G=-2 \ln \left(\frac{\text { likelihood tanpa variabel bebas }}{\text { likelihood dengan variabel bebas }}\right)$

dengan:

likelihood tanpa variabel bebas $=\left(\frac{n_{1}}{n}\right)^{n_{1}}\left(\frac{n_{0}}{n}\right)^{n_{0}}$

likelihood dengan variabel bebas $=\prod_{i=1}^{n} \widehat{\pi}_{l}^{y_{i}}\left(1-\widehat{\pi}_{l}\right)^{\left(1-y_{i}\right)}$

$n_{1}=$ banyaknya variabel dependen yang bernilai 1

$n_{0}=$ banyaknya variabel dependen yang bernilai 0

Daerah penerimaan:

Terima $\mathrm{H}_{0}$ jika $\mathrm{G} \leq \chi_{(\mathrm{p}, \alpha)}^{2}$

\subsubsection{Uji Wald}

Uji Wald dilakukan kepada masing-masing variabel independen pada model untuk mengetahui apakah masing-masing variabel tersebut memiliki pengaruh yang signifikan terhadap model atau tidak.

Hipotesis:

$\mathrm{H}_{0}: \beta_{j}=0$ untuk suatu $j$ tertentu; $j=0,1,2, \ldots, p$

$\mathrm{H}_{1}: \beta_{j} \neq 0$ dengan $j=1,2, \ldots, p$

Statistik uji:

$W_{j}=\left[\frac{\widehat{\beta_{J}}}{S E\left(\widehat{\left.\beta_{J}\right)}\right.}\right]^{2}$

dengan:

$j=0,1,2, \ldots, p$

Daerah penerimaan:

Terima $\mathrm{H}_{0}$ jika $W_{j} \leq \chi_{(\alpha, 1)}^{2}$

\subsection{Uji Kesesuaian Model}

Uji goodnes of fit merupakan uji yang dilakukan untuk mengetahui apakah ada perbedaan antara prediksi dan hasil observasi.

Hipotesis:

$\mathrm{H}_{0}$ : model sesuai (tidak ada perbedaan antara hasil observasi dengan hasil prediksi)

$\mathrm{H}_{1}$ : model tidak sesuai (ada perbedaan antara hasil observasi dengan hasil prediksi)

Statistik uji:

$\hat{C}=\sum_{k=1}^{g} \frac{\left(o_{k}-n_{k}^{\prime} \overline{\pi_{k}}\right)^{2}}{\left(n_{k}^{\prime} \overline{\pi_{k}}\right)\left(1-\overline{\pi_{k}}\right)}$

Dengan:

$o_{k}$ : Jumlah nilai variabel terikat pada grup ke- $k$

$\overline{\pi_{k}}$ : Rata-rata taksiran peluang pada grup ke- $k$

$g$ : Banyak grup 
$n_{k}^{\prime}$ : Banyak observasi pada grup ke- $k$

Daerah penerimaan:

Terima $\mathrm{H}_{0}$ jika $\hat{C} \leq \chi_{(\alpha, g-2)}^{2}$

\subsection{Odds Ratio}

Odds Ratio (OR) atau rasio peluang adalah suatu cara untuk mengukur hubungan antara variabel bebas dengan variabel terikat. OR membandingkan peluang hasil yang terjadi dengan suatu variabel bebas tertentu, dengan peluang hasil yang terjadi tanpa variabel bebas tersebut.

\subsection{R dan RStudio}

$\mathrm{R}$ merupakan salah satu software yang dapat digunakan untuk keperluan komputasi statistika. R dibuat pada tahun 1992 oleh Robert Gentleman dan Ross Ihaka di Universitas Auckland, New Zealand dengan basis open source. Salah satu software yang dapat mempermudah penggunaan $\mathrm{R}$ adalah RStudio. Fitur dalam RStudio yang dapat mempermudah proses komputasi adalah koreksi penulisan sintaks dan fitur bantuan (help) yang terintegrasi dalam RStudio

\subsection{R Shiny}

Selain dapat melakukan komputasi statistika, pengguna $\mathrm{R}$ juga dapat memvisualisasikan hasil analisisnya dalam bentuk GUI (Graphical User Interface). Paket dalam R yang dapat digunakan dalam pembuatan GUI antara lain adalah $t$ cltk, gWidgets, dan shiny. Paket shiny dikembangkan oleh pengembang RStudio untuk pembuatan aplikasi GUI pada R. Paket ini memungkinkan pengguna R membuat aplikasi interaktif hanya dengan menggunakan $\mathrm{R}$

\section{METODOLOGI PENELITIAN}

Data yang digunakan dalam tugas akhir ini merupakan data sekunder yaitu data sekunder yaitu data Survei Sosial Ekonomi Nasional (Susenas) Maret 2018 yang diambil dari Badan Pusat Statistik Provinsi Jawa Tengah untuk Kabupaten Brebes. Variabel yang digunakan dalam penelitian ini terbagi menjadi 2 yaitu variabel bebas dan variabel terikat, sebagai berikut:

Tabel 1. Variabel Penelitian

\begin{tabular}{cc}
\hline Variabel & Keterangan \\
\hline $\mathrm{Y}$ & Penerima Raskin \\
$\mathrm{X}_{1}$ & Kesanggupan Menyantap Makanan Sehat \\
$\mathrm{X}_{2}$ & Luas Lantai Rumah Tinggal Utama \\
$\mathrm{X}_{3}$ & Bahan Dinding Rumah Tinggal Utama \\
$\mathrm{X}_{4}$ & Bahan Lantai Rumah Tinggal Utama \\
$\mathrm{X}_{5}$ & Sumber Utama Penerangan \\
$\mathrm{X}_{6}$ & Daya Terpasang di Rumah Tinggal Utama \\
$\mathrm{X}_{7}$ & Jenis Bahan Bakar Utama \\
$\mathrm{X}_{8}$ & Jenjang Pendidikan Tertinggi Kepala Keluarga \\
$\mathrm{X}_{9}$ & Fasilitas Buang Air Besar \\
\hline
\end{tabular}

Software yang digunakan sebagai alat hitung adalah SPSS 23, R 3.6.2, dan $R$ Studio. Adapun langkah-langkah dalam analisis data adalah sebagai berikut: 
1. Input data.

2. Menghitung estimasi parameter untuk mendapatkan model awal.

3. Melakukan uji signifikansi, yaitu uji likelihood untuk menentukan apakah variabel bebas secara bersama-sama mempengaruhi variabel terikat atau tidak, dan uji Wald untuk menentukan ada tidaknya pengaruh masing-masing variabel bebas.

4. Mengeluarkan variabel bebas yang tidak mempengaruhi variabel terikat secara signifikan.

5. Melakukan uji likelihood dan Wald yang kedua jika ada variabel bebas yang dikeluarkan dari model.

6. Jika masih ada variabel bebas yang tidak signifikan, maka akan dilakukan lagi pengeluaran variabel yang tidak signifikan dan dilakukan lagi uji likelihood dan uji Wald sampai didapat model dengan variabel yang signifikan saja

7. Melakukan uji goodness of fit untuk menentukan sesuai atau tidaknya model.

8. Menentukan model akhir.

9. Mencari ketepatan klasifikasi model regresi logistik biner.

\section{HASIL DAN PEMBAHASAN}

\subsection{Pembentukan GUI R}

Keseluruhan struktur penampilan pada GUI R baik penempatan widget untuk melakukan input dan menampilkan output menggunakan ekspresi ui<-fluidPage(). Fungsi tersebut akan mendefinisikan jendela besar tampilan GUI. Pada penelitian ini, tipe file yang akan digunakan adalah .txt. Jendela GUI akan dibagi menjadi 2, sisi kiri akan dipakai untuk keperluan input, dan sisi kanan akan dibagi lagi menjadi beberapa tabpanel yang akan digunakan untuk menampilkan hasil komputasi. Pada bagian input akan menggunakan fungsi fileInput () untuk memasukan tipe data, checkboxInput () untuk menyatakan apakah data menggunakan header atau tidak, dan radioButtons () untuk memilih jenis separator antar kolom data. Tab yang akan ditampilkan pada sisi kanan antara lain summary data, model regresi, nilai rasio likelihood, hasil uji kesesuaian model, nilai odds ratio, dan nilai ketepatan klasifikasi.

\subsection{Analis is Data Menggunakan Regresi Logistik Biner}

Analisis dilakukan menggunakan GUI R yang sudah disusun melalui software $\mathrm{R}$ Studio 1.2.

\subsubsection{Model Awal}

Berdasarkan output dari GUI R dapat diketahui nilai estimasi parameter dari masing-masing variabel seperti pada Tabel 2:

Tabel 2. Estimasi Parameter Regresi Logistik Biner

\begin{tabular}{cc}
\hline Variabel & Estimasi Parameter $\beta$ \\
\hline Constant & 0,701 \\
$X_{1(1)}$ & $-1,189$ \\
$X_{2}$ & $-0,012$ \\
$X_{3(2)}$ & 13,82 \\
$X_{3(3)}$ & 0,895 \\
$X_{3(4)}$ & 0,269
\end{tabular}




\begin{tabular}{lc}
$X_{3(6)}$ & 13,63 \\
$X_{3(7)}$ & 14,41 \\
$X_{4(2)}$ & 0,349 \\
$X_{4(3)}$ & 14,89 \\
$X_{4(4)}$ & 1,165 \\
$X_{4(5)}$ & 14,6 \\
$X_{4(6)}$ & 0,85 \\
$X_{4(8)}$ & 0,706 \\
$X_{4(9)}$ & 14,89 \\
$X_{5(1)}$ & 2,365 \\
$X_{6(2)}$ & 0,855 \\
$X_{6(3)}$ & 0,975 \\
$X_{6(4)}$ & $-1,817$ \\
$X_{7(2)}$ & $-0,054$ \\
$X_{7(3)}$ & 0,049 \\
$X_{7(4)}$ & 1,996 \\
$X_{7(7)}$ & 15,26 \\
$X_{7(10)}$ & 1,938 \\
$X_{8(2)}$ & $-0,851$ \\
$X_{8(3)}$ & $-3,114$ \\
$X_{9(2)}$ & $-0,014$ \\
$X_{9(3)}$ & $-3,371$ \\
$X_{9(4)}$ & 14,1 \\
$X_{9(5)}$ & 0,566 \\
$X_{9(4)}$ & \\
\hline
\end{tabular}

sehingga didapatkan model awal regresi logistik biner seperti berikut:

$\pi\left(x_{i}\right)=\frac{e^{g\left(x_{i(j)}\right)}}{1+e^{g\left(x_{i(j)}\right)}}$

dengan

$$
\begin{aligned}
g\left(x_{i(j)}\right)= & 0,7005-1,189 X_{1(1)}-0,012 X_{2}+13,82 X_{3(2)}+0,895 X_{3(3)}+0,269 X_{3(4)}+ \\
& 13,63 X_{3(6)}+14,41 X_{3(7)}+0,349 X_{4(2)}+14,89 X_{4(3)}+1,165 X_{4(4)}+14,6 X_{4(5)}+ \\
& 0,85 X_{4(6)}+0,706 X_{4(8)}+14,89 X_{4(9)}+2,365 X_{5(1)}+0,855 X_{6(2)}+0,975 X_{6(3)}- \\
& 1,817 X_{6(4)}-0,054 X_{7(2)}+0,0487 X_{7(3)}+1,996 X_{7(4)}+15,26 X_{7(7)}+ \\
& 1,938 X_{7(10)}-0,851 X_{8(2)}-3,114 X_{8(3)}-0,014 X_{9(2)}-3,371 X_{9(3)}+14,1 X_{9(4)}+ \\
& 0,566 X_{9(5)}
\end{aligned}
$$

\subsubsection{Uji Rasio Likelihood}

Uji rasio likelihood digunakan untuk menguji apakah variabel-variabel bebas pada model regresi yang telah terbentuk secara bersama-sama memberi pengaruh yang 
signifikan dalam memprediksi variabel bebas. Output yang didapatkan berdasarkan GUI R adalah sebagai berikut:

Gambar 1. Output Uji Rasio Likelihood Model Awal

\begin{tabular}{|c|c|}
\hline R D:/Script-C-Shiny & \\
\hline
\end{tabular}

\section{Regresi Logistik Biner}
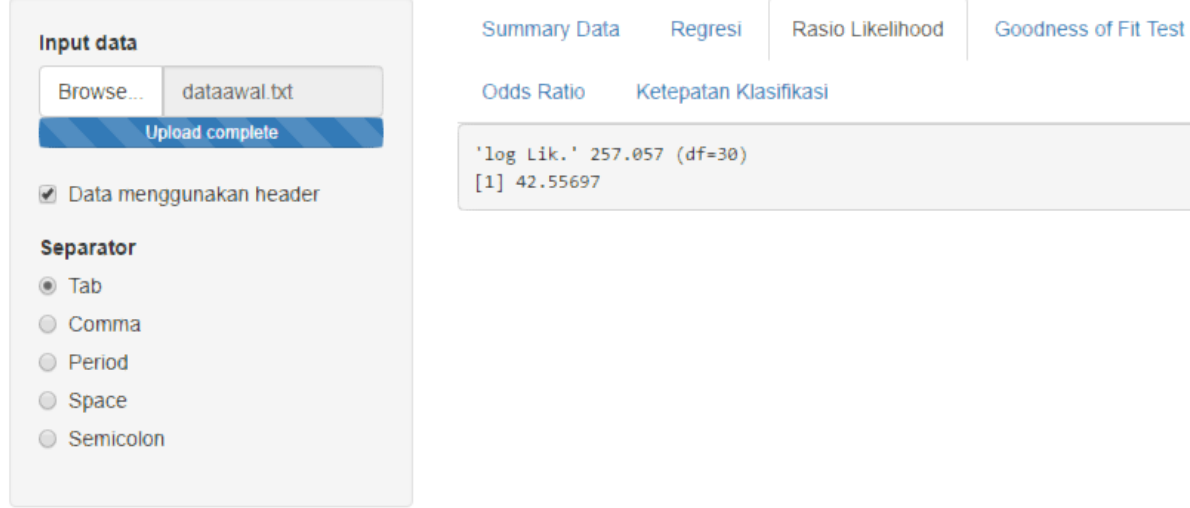

Hipotesis:

$\mathrm{H}_{0}: \beta_{1}=\beta_{2}=\cdots=\beta_{29}=0$

$\mathrm{H}_{1}$ : paling sedikit ada satu $\beta_{j} \neq 0$ dengan $j=1,2, \ldots, 29$

Taraf signifikansi:

$\alpha=5 \%$

Statistik Uji:

$G=257,057$ dan $\chi_{(29 ; 0,05)}^{2}=42,557$

Kriteria Uji:

$\mathrm{H}_{0}$ ditolak apabila nilai $G>\chi_{(29 ; 0,05)}^{2}$ dengan $\chi_{(29 ; 0,05)}^{2}=42,557$

Keputusan:

Karena nilai $G>\chi_{(29 ; 0,05)}^{2}$ yaitu $257,057>42,557$ maka $\mathrm{H}_{0}$ ditolak

Kesimpulan:

Karena $\mathrm{H}_{0}$ ditolak, maka dapat disimpulkan bahwa paling sedikit ada satu variabel independen pada model yang memberi pengaruh signifikan dalam memprediksi variabel bebas.

\subsubsection{Uji Wald}

Uji Wald dilakukan untuk mengetahui variabel-variabel bebas mana saja yang mempunyai pengaruh dalam memprediksi variabel terikat.

Hipotesis:

$\mathrm{H}_{0}: \beta_{j}=0$ dengan $j=1,2, \ldots, 29$

$\mathrm{H}_{1}: \beta_{j} \neq 0$ dengan $j=1,2, \ldots, 29$

Taraf signifikansi:

$\alpha=5 \%$

Statistik Uji:

$W_{j}=\left\{\frac{\widehat{\beta_{J}}}{S E\left(\widehat{\left.\beta_{J}\right)}\right.}\right\}^{2}$ 
Kriteria Uji:

$\mathrm{H}_{0}$ ditolak apabila nilai $p-$ value $<\alpha$

Keputusan:

Berdasarkan output, penolakan atau penerimaan $\mathrm{H}_{0}$ masing-masing variabel dapat dilihat pada Tabel 3 sebagai berikut:

Tabel 3. Uji Wald Model Awal

\begin{tabular}{|c|c|c|}
\hline Variabel & p-value & Keputusan \\
\hline$X_{1(1)}$ & 0,033 & $\mathrm{H}_{0}$ ditolak \\
\hline$X_{2}$ & $7,27 \mathrm{E}-08$ & $\mathrm{H}_{0}$ ditolak \\
\hline$X_{3(2)}$ & 0,989 & $\mathrm{H}_{0}$ diterima \\
\hline$X_{3(3)}$ & 0,399 & $\mathrm{H}_{0}$ diterima \\
\hline$X_{3(4)}$ & 0,699 & $\mathrm{H}_{0}$ diterima \\
\hline$X_{3(6)}$ & 0,992 & $\mathrm{H}_{0}$ diterima \\
\hline$X_{3(7)}$ & 0,990 & $\mathrm{H}_{0}$ diterima \\
\hline$X_{4(2)}$ & 0,631 & $\mathrm{H}_{0}$ diterima \\
\hline$X_{4(3)}$ & 0,993 & $\mathrm{H}_{0}$ diterima \\
\hline$X_{4(4)}$ & 0,166 & $\mathrm{H}_{0}$ diterima \\
\hline$X_{4(5)}$ & 0,995 & $\mathrm{H}_{0}$ diterima \\
\hline$X_{4(6)}$ & 0,280 & $\mathrm{H}_{0}$ diterima \\
\hline$X_{4(8)}$ & 0,411 & $\mathrm{H}_{0}$ diterima \\
\hline$X_{4(9)}$ & 0,993 & $\mathrm{H}_{0}$ diterima \\
\hline$X_{5(1)}$ & 0,088 & $\mathrm{H}_{0}$ diterima \\
\hline$X_{6(2)}$ & 0,058 & $\mathrm{H}_{0}$ diterima \\
\hline$X_{6(3)}$ & 0,032 & $\mathrm{H}_{0}$ ditolak \\
\hline$X_{6(4)}$ & 0,189 & $\mathrm{H}_{0}$ diterima \\
\hline$X_{7(2)}$ & 0,979 & $\mathrm{H}_{0}$ diterima \\
\hline$X_{7(3)}$ & 0,979 & $\mathrm{H}_{0}$ diterima \\
\hline$X_{7(4)}$ & 0,221 & $\mathrm{H}_{0}$ diterima \\
\hline$X_{7(7)}$ & 0,995 & $\mathrm{H}_{0}$ diterima \\
\hline$X_{7(10)}$ & 0,244 & $\mathrm{H}_{0}$ diterima \\
\hline$X_{8(2)}$ & 8,76E-04 & $\mathrm{H}_{0}$ ditolak \\
\hline$X_{8(3)}$ & $6,41 \mathrm{E}-11$ & $\mathrm{H}_{0}$ ditolak \\
\hline$X_{9(2)}$ & 0,968 & $\mathrm{H}_{0}$ diterima \\
\hline$X_{9(3)}$ & 8,84E-03 & $\mathrm{H}_{0}$ ditolak \\
\hline$X_{9(4)}$ & 0,995 & $\mathrm{H}_{0}$ diterima \\
\hline$X_{9(5)}$ & 0,191 & $\mathrm{H}_{0}$ diterima \\
\hline
\end{tabular}

Kesimpulan:

Dari uji parameter secara individu, dapat disimpulkan bahwa variabel bebas yang memberikan pengaruh secara signifikan dalam memprediksi variabel terikat adalah variabel $X_{1}$ yaitu kesanggupan menyantap makanan sehat, $X_{2}$ yaitu luas rumah tinggal utama, $X_{6}$ yaitu daya terpasang di rumah tinggal utama, $X_{8}$ yaitu pendidikan kepala rumah tangga, $X_{9}$ yaitu fasilitas buang air besar. 


\subsubsection{Model Baru}

Berdasarkan output dari GUI R didapatkan estimasi parameter dari masing-masing variabel seperti pada Tabel 4 berikut:

Tabel 4. Estimasi Parameter Regresi Logistik Biner

\begin{tabular}{cc}
\hline Variabel & Estimasi Parameter $\beta$ \\
\hline Constant & 3,298 \\
$X_{1(1)}$ & $-1,277$ \\
$X_{2}$ & $-0,013$ \\
$X_{6(2)}$ & 0,884 \\
$X_{6(3)}$ & 1,066 \\
$X_{6(4)}$ & 0,532 \\
$X_{8(2)}$ & $-0,994$ \\
$X_{8(3)}$ & $-3,434$ \\
$X_{9(2)}$ & $-0,001$ \\
$X_{9(3)}$ & $-2,954$ \\
$X_{9(4)}$ & 11,419 \\
$X_{9(5)}$ & 0,871 \\
\hline
\end{tabular}

$\pi\left(x_{i}\right)=\frac{e^{g\left(x_{i(j)}\right)}}{1+e^{g\left(x_{i(j)}\right)}}$

dengan

$g\left(x_{i(j)}\right)=3,298-1,277 X_{1(1)}-0,013 X_{2}+0,884 X_{6(2)}+1,066 X_{6(3)}-0,532 X_{6(4)}-$

$0,994 X_{8(2)}-3,434 X_{8(3)}-0,001 X_{9(2)}-2,954 X_{9(3)}+11,419 X_{9(4)}+0,871 X_{9(5)}$

\subsubsection{Uji Rasio Likelihood Tahap Kedua}

Uji rasio likelihood tahap kedua digunakan untuk menguji apakah variabelvariabel bebas pada model regresi yang baru secara bersama-sama memberi pengaruh yang signifikan dalam memprediksi variabel bebas. Output yang didapatkan berdasarkan GUI R adalah sebagai berikut:

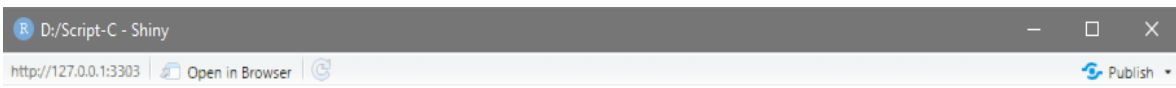

\section{Regresi Logistik Biner}
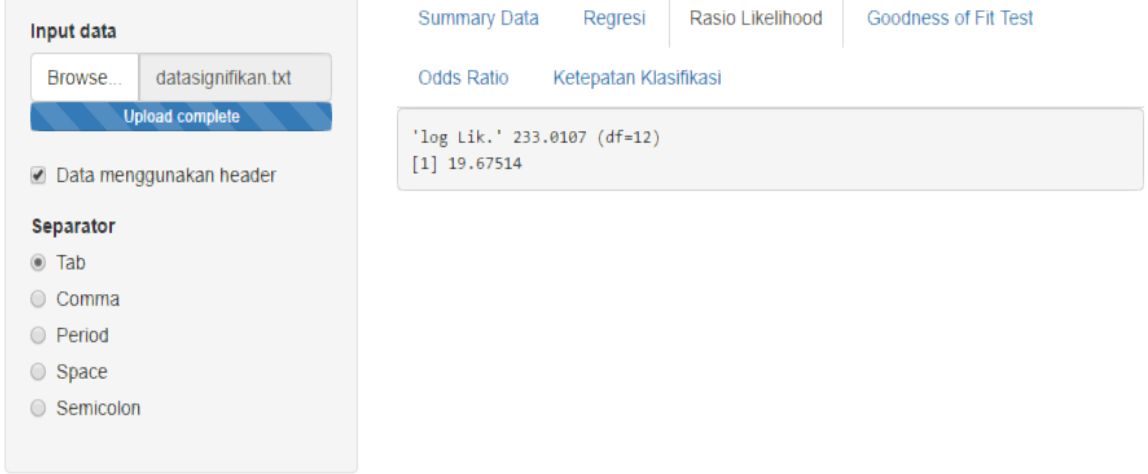

Gambar 2. Uji Rasio Likelihood Model Kedua 
Hipotesis:

$\mathrm{H}_{0}: \beta_{1}=\beta_{2}=\cdots=\beta_{11}=0$

$\mathrm{H}_{1}$ : paling sedikit ada satu $\beta_{j} \neq 0$ dengan $j=1,2, \ldots, 11$

Taraf signifikansi:

$\alpha=5 \%$

Statistik Uji:

$G=233,0107$ dan $\chi_{(11 ; 0,05)}^{2}=19,67514$

Keputusan:

Karena nilai $G>\chi_{(11 ; 0,05)}^{2}$ yaitu $233,0107>19,67514$ maka $\mathrm{H}_{0}$ ditolak

Kesimpulan:

Karena $\mathrm{H}_{0}$ ditolak, maka dapat disimpulkan bahwa paling sedikit ada satu variabel independen pada model kedua yang memberi pengaruh signifikan dalam memprediksi variabel bebas.

\subsubsection{Uji Wald Tahap Kedua}

Uji Wald tahap kedua dilakukan untuk mengetahui variabel-variabel bebas mana saja yang mempunyai pengaruh dalam memprediksi variabel terikat pada model kedua. Hipotesis:

$\mathrm{H}_{0}: \beta_{j}=0$ dengan $j=1,2, \ldots, 11$

$\mathrm{H}_{1}: \beta_{j} \neq 0$ dengan $j=1,2, \ldots, 11$

Taraf signifikansi: $\alpha=5 \%$

Statistik Uji: $W_{j}=\left\{\frac{\widehat{\beta_{J}}}{S E\left(\widehat{\left.\beta_{j}\right)}\right.}\right\}^{2}$

Kriteria Uji:

$\mathrm{H}_{0}$ ditolak apabila nilai $p-$ value $<\alpha$

Keputusan:

Penolakan atau penerimaan $\mathrm{H}_{0}$ masing-masing variabel dapat dilihat pada Tabel 5 sebagai berikut:

Tabel 5. Uji Wald Model Kedua

\begin{tabular}{ccc}
\hline Variabel & $\mathrm{p}$-value & Keputusan \\
\hline$X_{1(1)}$ & 0,0197 & $\mathrm{H}_{0}$ ditolak \\
$X_{2}$ & $2,04 \mathrm{E}-09$ & $\mathrm{H}_{0}$ ditolak \\
$X_{6(2)}$ & 0,0432 & $\mathrm{H}_{0}$ ditolak \\
$X_{6(3)}$ & 0,0157 & $\mathrm{H}_{0}$ ditolak \\
$X_{6(4)}$ & $\mathrm{H}_{0}$ diterima \\
$X_{8(2)}$ & 0,331 & $\mathrm{H}_{0}$ ditolak \\
$X_{8(3)}$ & $5,58 \mathrm{E}-05$ & $\mathrm{H}_{0}$ ditolak \\
$X_{9(2)}$ & $1,48 \mathrm{E}-13$ & $\mathrm{H}_{0}$ diterima \\
$X_{9(3)}$ & 0,9969 & $\mathrm{H}_{0}$ ditolak \\
$X_{9(4)}$ & 0,0177 & $\mathrm{H}_{0}$ diterima \\
$X_{9(5)}$ & 0,983 & $\mathrm{H}_{0}$ ditolak \\
\hline
\end{tabular}


Kesimpulan:

Dari uji parameter secara individu, dapat disimpulkan bahwa semua variabel bebas pada model kedua memberikan pengaruh secara signifikan dalam memprediksi variabel terikat.

\subsubsection{Uji Kesesuaian Model}

Uji kesesuaian model dilakukan untuk mengetahui apakah ada perbedaan antara prediksi dan hasil observasi. Output yang didapatkan berdasarkan GUI R adalah sebagai berikut:

Gambar 3. Output Uji Kesesuaian Model Model Kedua

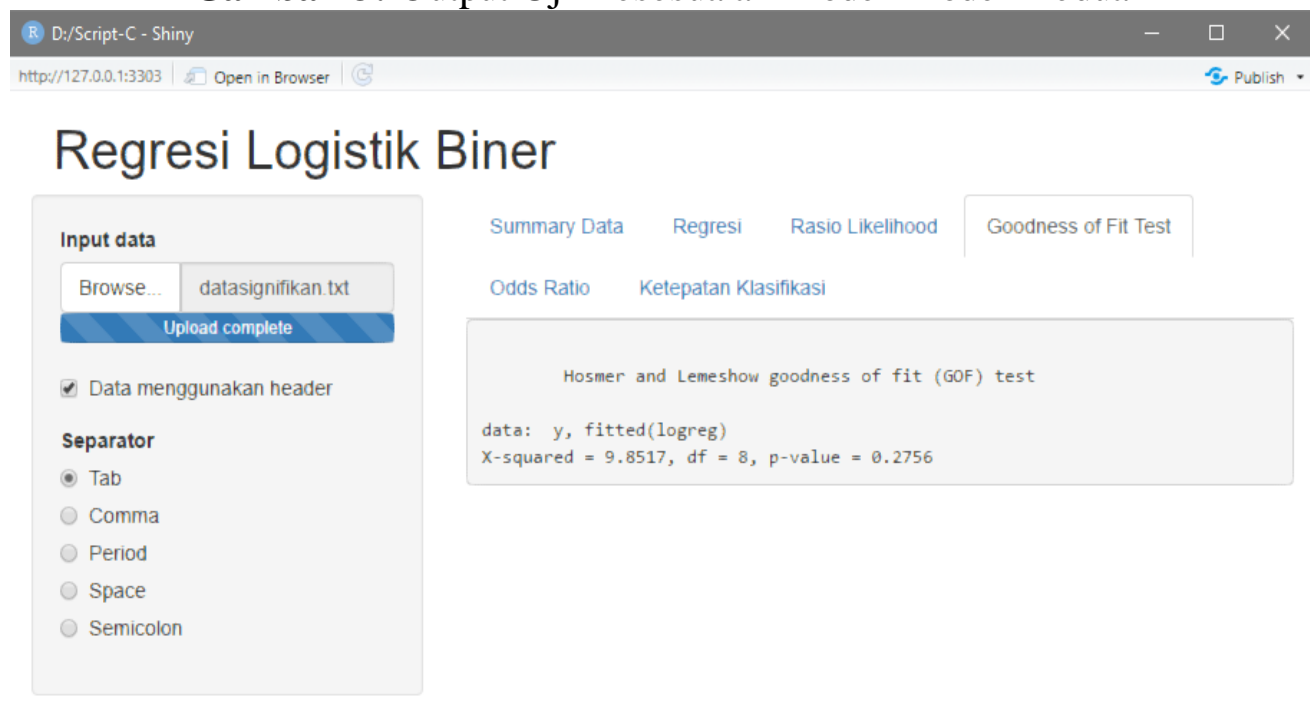

Hipotesis:

$\mathrm{H}_{0}$ : Model sesuai (tidak ada perbedaan antara hasil observasi dengan hasil prediksi)

$\mathrm{H}_{1}$ : Model tidak sesuai (ada perbedaan antara hasil observasi dengan hasil prediksi)

Taraf signifikansi:

$\alpha=5 \%$

Statistik Uji:

$\hat{C}=\sum_{k=1}^{g} \frac{\left(o_{k}-n_{k}^{\prime} \overline{\pi_{k}}\right)^{2}}{\left(n_{k}^{\prime} \overline{\pi_{k}}\right)\left(1-\bar{\pi}_{k}\right)}$

Kriteria Uji:

$\mathrm{H}_{0}$ diterima apabila nilai $p-$ value $>\alpha$

Keputusan:

Karena $p$-value $>\alpha$ yaitu $0,2756>0,05$ maka $\mathrm{H}_{0}$ diterima

Kesimpulan:

Karena $\mathrm{H}_{0}$ diterima, maka dapat disimpulkan bahwa pada model kedua tidak ada perbedaan antara hasil observasi dengan hasil prediksi.

\subsubsection{Model Akhir}

Model akhir yang didapatkan adalah:

$\pi\left(x_{i}\right)=\frac{e^{g\left(x_{i(j)}\right)}}{1+e^{g\left(x_{i(j)}\right)}}$

dengan

$g\left(x_{i(j)}\right)=3,298-1,277 X_{1(1)}-0,013 X_{2}+0,884 X_{6(2)}+1,066 X_{6(3)}-0,532 X_{6(4)}-$ 
$0,871 X_{9(5)}$

$$
0,994 X_{8(2)}-3,434 X_{8(3)}-0,001 X_{9(2)}-2,954 X_{9(3)}+11,419 X_{9(4)}+
$$

\subsubsection{Ketepatan Klasifikasi}

Akurasi model yang terbentuk dapat diukur dengan menggunakan tabel klasifikasi. Tabel klasifikasi ditujukan untuk melihat banyaknya data yang dikategorikan sebagai keluarga yang menerima atau membeli raskin dan keluarga yang tidak menerima atau membeli raskin. Hasil dari tabel klasifikasi dapat dilihat pada Gambar 4:

Gambar 4. Output Ketepatan Klasifikasi

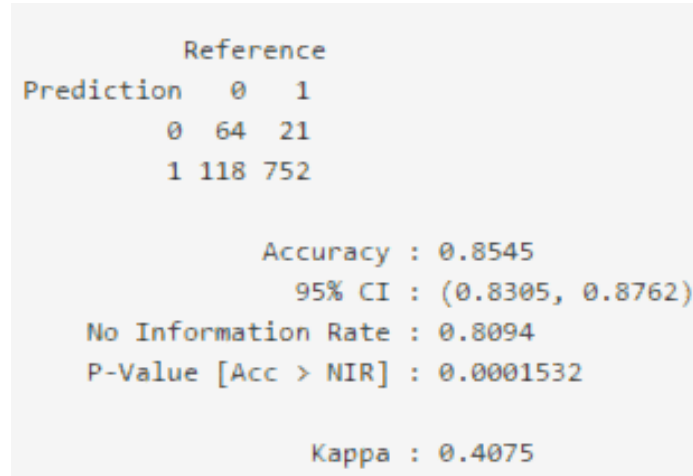

Berdasarkan Gambar 4, didapatkan data tabel klasifikasi dan dapat dibentuk matriks konfusi seperti pada Tabel 6:

Tabel 6. Matriks Konfusi Regresi Logistik Biner

\begin{tabular}{|c|c|c|}
\hline \multirow{2}{*}{ Observasi } & \multicolumn{2}{|c|}{ Prediksi } \\
\cline { 2 - 3 } & $\begin{array}{c}\text { Tidak menerima atau } \\
\text { membeli raskin }\end{array}$ & $\begin{array}{c}\text { Menerima atau membeli } \\
\text { raskin }\end{array}$ \\
\hline $\begin{array}{c}\text { Tidak menerima atau } \\
\text { membeli raskin }\end{array}$ & 64 & 118 \\
\hline $\begin{array}{c}\text { Menerima atau membeli } \\
\text { raskin }\end{array}$ & 21 & 752 \\
APER $=\frac{118+21}{64+21+118+752}$ \\
$=0,146$ \\
$\begin{aligned} \text { Akurasi } & =100 \% \times(1-\text { APER }) \\
& =100 \% \times 0,854 \\
& =85,4 \%\end{aligned}$
\end{tabular}

Berarti dalam percobaan pengklasifikasian penerimaan atau pembelian raskin menggunakan 955 data, model akhir yang didapatkan mampu mengklasifikasikan secara tepat sebanyak 816 data.

\section{KESIMPULAN}

Berdasarkan hasil analisis dan pembahasan yang telah diuraikan pada bab sebelumnya, maka diperoleh kesimpulan sebagai berikut:

1. Faktor-faktor yang mempengaruhi penerimaan atau pembelian raskin adalah kesanggupan menyantap makanan sehat, luas lantai rumah utama, daya terpasang di rumah utama, jenjang pendidikan tertinggi kepala keluarga, dan fasilitas buang air besar. 
2. Model akhir regresi logistik biner yang didapatkan adalah sebagai berikut:

$\pi\left(x_{i}\right)=\frac{e^{g\left(x_{i(j)}\right)}}{1+e^{g\left(x_{i(j)}\right)}}$

dengan

$$
\begin{aligned}
g\left(x_{i(j)}\right)= & 3,298-1,277 x_{1(1)}-0,013 x_{2}+0,884 x_{6(2)}+1,066 x_{6(3)}- \\
& 0,532 x_{6(4)}-0,994 x_{8(2)}-3,434 x_{8(3)}-0,001 x_{9(2)}- \\
& 2,954 x_{9(3)}+11,419 x_{9(4)}+0,871 x_{9(5)}
\end{aligned}
$$

3. Nilai akurasi pengklasifikasian penerimaan atau pembelian raskin di kabupaten Brebes menggunakan regresi logistik biner adalah $85,4 \%$ dengan nilai APER atau error $14,6 \%$.

\section{DAFTAR PUSTAKA}

Agresti, A. (2019). An Introduction to Categorical Data Analysis. Hoboken: John Wiley \& Sons, Inc.

Bulog. (2019, 11 23). Sekilas Raskin. Diambil kembali dari Perum Bulog: http://www.bulog.co.id/sekilas_raskin.php

Hosmer, D. W., \& Lemeshow, S. (2000). Applied Logistic Regression. Hoboken: John Wiley \& Sons, Inc.

Kementerian Sosial RI. (2012). Analisis Data Kemiskinan Berdasarkan Data Pendataan Program Perlindungan Sosial. Jakarta: Kementerian Sosial RI.

Nachrowi, N. D., \& Usman, H. (2002). Penggunaan Teknik Ekonometri. Jakarta:PT. RajaGrafindo Persada. 